Muntoha. Demokrasi dan Negara...

\title{
Demokrasi dan Negara Hukum
}

\author{
Muntoha \\ Fakultas Hukum Universitas Islam Indonesia Yogyakarta \\ muntoha@fh.uii.ac.id
}

\begin{abstract}
The rule of law state shall be based on democracy. This because there is a correlation between a rule of law state which relies on a constitution and sovereignty of the people which is run by democracy. In democracy, public's participation is a core essence. However, democracy without a robust regulation will lose its direction, and similarly, law without democracy will lose its true meaning. As a result, in a democratic rule of law state, law is developed and enforced in accordance with the principle of democracy. Law must not be made, approved, interpreted, and enforced merely by power (machstaat), but rather this shall be regulated by law (rechstaat).
\end{abstract}

Keywords: democracy, rule of law

\section{Pengantar}

Demokrasi dan negara hukum adalah dua konsepsi mekanisme kekuasan dalam menjalankan roda pemerintahan negara. Kedua konsepsi tersebut saling berkaitan yang satu sama lainnya tidak dapat dipisahkan, karena pada satu sisi demokrasi memberikan landasan dan mekanisme kekuasaan berdasarkan prinsip persamaan dan kesederajatan manusia, pada sisi yang lain negara hukum memberikan patokan bahwa yang memerintah dalam suatu negara bukanlah manusia, tetapi hukum.

Dalam tataran praksis, prinsip demokrasi atau kedaulatan rakyat dapat menjamin peran serta masyarakat dalam proses pengambilan keputusan, sehingga setiap peraturan perundang-undangan yang diterapkan dan ditegakkan benar-benar mencerminkan perasaan keadilan masyarakat. Sedangkan dalam negara yang berdasarkan atas hukum, dalam hal ini hukum harus dimaknai sebagai kesatuan hirarkis tatanan norma hukum yang berpuncak pada konstitusi. Hal ini berarti bahwa 
dalam suatu negara hukum menghendaki adanya supremasi konstitusi. Supremasi konstitusi, di samping merupakan konsekuensi dari konsep negara hukum, sekaligus merupakan pelaksanaan demokrasi karena konstitusi adalah wujud perjanjian sosial tertinggi. ${ }^{1}$ Berdasarkan teori kontrak sosial, untuk memenuhi hak-hak tiap manusia, tidak mungkin dicapai masing-masing orang secara individual, tetapi harus bersamasama. Maka, dibuatlah perjanjian sosial yang berisi tentang tujuan bersama, batas-batas hak individual, dan siapa yang bertanggung jawab untuk pencapaian tujuan tersebut dan menjalankan perjanjian yang telah dibuat dengan batas-batasnya. Perjanjian tersebut diwujudkan dalam bentuk konstitusi sebagai hukum tertinggi di suatu negara (the supreme law of the land), yang kemudian dielaborasi secara konsisten dalam hukum dan kebijakan negara. ${ }^{2}$

Oleh karena itu, hukum dan peraturan perundang-undangan yang berlaku tidak boleh ditetapkan secara sepihak oleh dan atau hanya untuk kepentingan penguasa. Hal ini bertentangan dengan prinsip demokrasi, karena hukum tidak dimaksudkan hanya untuk menjamin kepentingan beberapa orang yang berkuasa, melainkan menjamin kepentingan keadilan bagi semua orang sehingga negara hukum yang dikembangkan bukan absolute rechtsstaat, tetapi demcratische rechtsstaat. ${ }^{3}$

\section{Konsepsi Demokrasi}

Konsepsi demokrasi selalu menempatkan rakyat pada posisi yang sangat strategis dalam sistem ketatanegaraan, walaupun pada tataran implementasinya terjadi perbedaan antara negara yang satu dengan negara yang lain. Karena berbagai varian implementasi demokrasi tersebut, maka di dalam literatur kenegaraan dikenal beberapa istilah demokrasi yaitu demokrasi konstitusional, demokrasi parlementer, demokrasi terpimpin, demokrasi Pancasila, demokrasi rakyat, demokrasi soviet, demokrasi nasional, dan lain sebagainya. ${ }^{4}$ Semua konsep ini memakai

${ }^{1}$ Jimly Asshiddiqie, Konstitusi dan Konstitusionalisme Indonesia, Edisi Revisi, Konstitusi Press, Jakarta, 2005, hlm. 152 - 162.

2Jimly Asshiddiqie, Menuju Negara Hukum Yang Demokratis,Sekretariat Jenderal dan Kepaniteraan Mahkamah Konstiusi, Jakarta, 2008, hlm. 532.

${ }^{3}$ Ibid., hlm. 532.

${ }^{4}$ Untuk kepentingan pemahaman secara komprehensif terhadap istilah-istilah demokrasi tersebut, baca lebih lanjut: Moh. Koesnardi dan Bintan R. Saragih, Ilmu Negara, Cetakan ke-2, Gaya Media Pratama, Jakarta, 1988, hlm. 167 - 191. 
istilah demokrasi, yang menurut asal kata berarti "rakyat berkuasa" atau government or rule by the people (kata Yunani demos berarti rakyat, kratos/ kratein berarti kekuasaan/berkuasa). ${ }^{5}$

Sementara itu, Sidney Hook memberikan definisi tentang demokrasi sebagai bentuk pemerintahan di mana keputusan-keputusan pemerintah yang penting atau arah kebijakan di balik keputusan secara langsung didasarkan pada keputusan mayoritas yang diberikan secara bebas dari rakyat dewasa. ${ }^{6}$ Hal ini berarti bahwa pada tingkat terakhir rakyat memberikan ketentuan dalam masalah-masalah pokok mengenai kehidupan mereka, termasuk dalam menilai kebijaksanaan negara yang turut menentukan kehidupan mereka tersebut. ${ }^{7}$ Oleh karena itu, demokrasi sebagai suatu gagasan politik di dalamnya terkandung 5 (lima) kriteria, yaitu: ${ }^{8}(1)$ persamaan hak pilih dalam menentukan keputusan kolektif yang mengikat; (2) partisipasi efektif, yaitu kesempatan yang sama bagi semua warga negara dalam proses pembuatan keputusan secara kolektif, (3) pembeberan kebenaran, yaitu adanya peluang yang sama bagi setiap orang untuk memberikan penilaian terhadap jalannya proses politik dan pemerintahan secara logis, (4) kontrol terakhir terhadap agenda, yaitu adanya keputusan eksklusif bagi masyarakat untuk menentukan agenda mana yang harus dan tidak harus diputuskan melalui proses pemerintahan, termasuk mendelegasikan kekuasaan itu pada orang lain atau lembaga yang mewakili masyarakat, dan (5) pencakupan, yaitu terliputnya masyarakat mencakup semua orang dewasa dalam kaitannya dengan hukum.

Secara komprehensif kriteria demokrasi juga diajukan oleh Gwendolen M. Carter, John H. Herz dan Henry B. Mayo. Carter dan Herz mengkonseptualisasikan demokrasi sebagai pemerintahan yang dicirikan oleh dan dijalankannya melalui prinsip-prinsip: ${ }^{9}$ (1) pembatasan terhadap tindakan pemerintah untuk memberikan perlindungan bagi individu dan

${ }^{5}$ Miriam Budiardjo, Dasar-dasar Ilmu Politik, Cetakan ke-7, Gramedia, Jakarta, 1996, hlm. 50.

${ }^{6}$ Sidney Hook dalam Nakamura dan Samallowood, The Polities of Policy Implementation, st. Martin's Press, New York, 1980, hlm. 67.

${ }^{7}$ Deliar Noer, Pengantar ke Pemikiran Politik, CV. Rajawali, Jakarta, 1983, hlm. 207.

${ }^{8}$ Robert A. Dahl, Dilema Demokrasi Pluralis: Antara Otonomi dan Kontrol, terjemahan Sahat Simamora, Rajawali Press, Jakarta, 1985, hlm. 19 - 20.

${ }^{9}$ Gwendolen M. Carter dan John Herz, Peranan Pemerintah dalam Masyarakat Masa Kini, dalam Miriam Budiardjo, Masalah Kenegaraan, Gramedia, Jakarta, 1982, hlm. $86-87$. 
kelompok dengan jalan menyusun pergantian pimpinan secara berkala, tertib dan damai, dan melalui alat-alat perwakilan rakyat yang efektif; (2) adanya sikap toleransi terhadap pendapat yang berlawanan; (3) persamaan di depan hukum yang diwujudkan dengan sikap tunduk kepada rule of law tanpa membedakan kedudukan politik; (4) adanya pemilihan yang bebas dengan disertai adanya model perwakilan yang efektif; (5) diberinya kebebasan partisipasi dan beroposisi bagi partai politik, organisasi kemasyarakatan, masyarakat dan perseorangan serta prasarana pendapat umum semacam pers dan media massa; (6) adanya penghormatan terhadap hak rakyat untuk menyatakan pandangannya betapa pun tampak salah dan tidak populernya pandangan itu; dan (7) dikembangkannya sikap menghargai hak-hak minoritas dan perorangan dengan lebih mengutamakan penggunaan cara-cara persuasif dan diskusi daripada koersif dan represif.

Sedangkan Henry B. Mayo menyatakan bahwa nilai-nilai yang harus dipenuhi untuk kriteria demokrasi adalah: ${ }^{10}(1)$ menyelesaikan pertikaianpertikaian secara damai dan sukarela; (2) menjamin terjadinya perubahan secara damai dalam suatu masyarakat yang selalu berubah; (3) pergantian penguasa dengan teratur; (4) pengunaan pemaksaan seminimal mungkin; (5) pengakuan dan penghormatan terhadap nilai-nilai keanekaragaman; (6) menegakkan keadilan; (7) memajukan ilmu pengetahuan; dan (8) pengakuan dan penghormatan terhadap kebebasan.

Dalam pandangan lain, demokrasi sebagai suatu gagasan politik merupakan paham yang universal sehingga di dalamnya terkandung beberapa elemen sebagai berikut: ${ }^{11}$

1. Penyelenggara kekuasaan berasal dari rakyat;

2. Setiap pemegang jabatan yang dipilih oleh rakyat harus dapat mempertanggungjawabkan kebijaksanaan yang hendak dan telah ditempuhnya;

3. Diwujudkan secara langsung maupun tidak langsung;

4. Rotasi kekuasaan dari seseorang atau kelompok ke orang atau kelompok yang lainnya, dalam demokrasi peluang akan terjadinya rotasi kekuasaan harus ada, dan dilakukan secara teratur dan damai;

5. Adanya proses pemilu, dalam negara demokratis pemilu dilakukan secara teratur dalam menjamin hak politik rakyat untuk memilih dan dipilih; dan

\footnotetext{
${ }^{10}$ Henry B. Mayo dalam Miriam Budiardjo, Ibid., hlm. 165 - 191.

${ }^{11}$ Afan Gaffar, Politik Indonesia; Transisi Menuju Demokrasi, Pustaka Pelajar, Yogyakarta, 2005, hlm. 15.
} 
6. Adanya kebebasan sebagai HAM, menikmati hak-hak dasar, dalam demokrasi setiap warga masyarakat dapat menikmati hak-hak dasarnya secara bebas, seperti hak untuk menyatakan pendapat, berkumpul dan berserikat dan lain-lain.

Dalam rangka mengimplementasikan semua kriteria, prinsip, nilai, dan elemen-elemen demokrasi tersebut di atas, perlu disediakan beberapa lembaga sebagai berikut:12

1. Pemerintahan yang bertanggung jawab;

2. Suatu Dewan Perwakilan Rakyat yang mewakili golongan-golongan dan kepentingan-kepentingan dalam masyarakat yang dipilih dengan pemilihan umum yang bebas dan rahasia dan atas dasar sekurangkurangnya dua calon untuk setiap kursi. Dewan/perwakilan ini mengadakan pengawasan (kontrol) memungkinkan oposisi yang konstruktif dan memungkinkan penilaian terhadap kebijakan pemerintah secara kontinyu;

3. Suatu organisasi politik yang mencakup satu atau lebih partai politik. Partai-partai menyelenggarakan hubungan yang kontinyu antara masyarakat umum dan pemimpin-pemimpinnya;

4. Pers dan media massa yang bebas untuk menyatakan pendapat; dan

5. Sistem peradilan yang bebas untuk menjamin hak-hak asasi dan mempertahankan keadilan.

Itulah landasan mekanisme kekuasaan yang diberikan oleh konsepsi demokrasi, yang mendasarkan pada prinsip persamaan dan kesederajatan manusia. Pada hakikatnya, kekuasaan dalam suatu organisasi dapat diperoleh berdasarkan legitimasi religious, legitimasi ideologis eliter, atau legitimasi pragmatis. ${ }^{13}$ Namun, kekuasaan berdasarkan legitimasi-legitimasi tersebut, dengan sendirinya, mengingkari kesamaan dan kesederajatan manusia, karena mengklaim kedudukan lebih tinggi sekelompok manusia dari manusia lainnya. Selain itu, kekuasaan yang berdasarkan ketiga legitimasi tersebut akan menjadi kekuasaan yang absolut, karena asumsi dasarnya menempatkan kelompok yang memerintah sebagai pihak yang berwenang secara istimewa dan lebih tahu dalam menjalankan urusan kekuasaan negara. Kekuasaan yang didirikan berdasarkan ketiga legitimasi tersebut bisa dipastikan akan menjadi kekuasaan yang otoriter. ${ }^{14}$

${ }^{12}$ Moh. Koesnardi dan Bintan R. Saragih, Op. Cit., hlm. 171.

${ }^{13}$ Frans Magnis Suseno, Etika Politik: Prinsip-prinsip Moral Dasar Kenegaraan Modern, PT. Gramedia Pustaka Utama, Jakarta, 1999, hlm. 30 - 66.

${ }^{14}$ Jimly Asshiddiqie, Menuju Negara Hukum Yang Demokratis, Op. Cit., hlm. 532. 
Dengan demikian, kekuasaan yang diperoleh melalui mekanisme demokrasi, karena konsepsi demokrasi menempatkan manusia sebagai pemilik kedaulatan yang kemudian dikenal dengan prinsip kedaulatan rakyat, maka bisa dipastikan akan menjadi kekuasaan yang demokratis karena kehendak rakyatlah sebagai landasan legitimasinya.

\section{Konsepsi Negara Hukum}

Secara historis, gagasan tentang konsepsi negara hukum terus bergulir sejalan dengan arus perkembangan sejarah. Mulai dari konsepsi negara hukum liberal (nachwachter staat/negara sebagai penjaga malam) ke negara hukum formal (formele rechtsstaat) kemudian menjadi negara hukum materiil (materiele rechtsstaat) hingga pada ide negara kemakmuran (welvarstaat) atau negara yang mengabdi kepada kepentingan umum (social service state atau sociale verzorgingsstaat). ${ }^{15}$

Negara hukum liberal atau yang sering disebut sebagai negara hukum dalam arti sempit adalah konsepsi yang diberikan oleh Immanuel Kant (1724 - 1804 SM), yang kemunculannya bersamaan dengan lahirnya faham liberalisme yang menentang kekuasaan absolut dari para raja pada masa itu. ${ }^{16}$ Menurut faham liberalisme negara justeru harus melepaskan dirinya dari campur tangan urusan kepentingan rakyatnya, yang berarti sikap negara harus pasif (staatsonthouding). Hal ini berpengaruh pada bentuk negara dan bentuk pemerintahan yang kemudian menjadi monarchi konstitusional, yaitu adanya pembatasan kekuasaan raja oleh konstitusi sebagai akibat dari perjanjian yang dilakukan dengan rakyatnya yang menentukan kedua belah pihak dalam kedudukan yang sama. ${ }^{17}$ Oleh karena itu, tipe negaranya pada masa itu adalah negara hukum liberal

${ }^{15}$ Padmo Wahjono, Membudayakan UUD 1945, IND HILL-Co, Jakarta, 1991, hlm. 73.

${ }^{16}$ Faham liberalism terlahir sebagai antithesis dari faham mercantilisme yang ketika itu tumbuh subur di Perancis pada masa pemerintahan Lodewijk XIV, Spanyol, Portugal, sementara di Jerman dan Austria faham mercantilisme tersebut bernama kamerwissenchaft. Faham ini menghendaki suatu neraca perdagangan yang positif (activehandelbalance), maka hal ini berpengaruh kepada bentuk negara dan bentuk pemerintahan yaitu monarchi absolut, di mana raja lah yang menentukan segalagalanya untuk rakyatnya sendiri. Artinya, walaupun raja mau menyelenggarakan kepentingan rakyat, tetapi rakyat tidak boleh ikut campur tangan (Lihat: Moh Koesnardi dan Harmaily Ibrahim, Pengantar Hukum Tata Negara, Cetakan ke-7, Pusat Studi HTN FH-UI, Jakarta, 1988, hlm. 155).

${ }^{17}$ Ibid., hlm. 156. 
(nachwachterstaat). Dalam negara hukum liberal ini terdapat jaminan bahwa setiap warga negara mempunyai kedudukan hukum yang sama dan tidak boleh diperlakukan sewenang-wenang oleh penguasa. Maka, untuk mencapai tujuan ini, negara harus mengadakan pemisahan kekuasaan yang masing-masing mempunyai kedudukan yang sama tinggi dan sama rendah, tidak boleh saling mempengaruhi dan tidak boleh campur tangan satu sama lain sehingga untuk dapat disebut sebagai negara hukum dalam tipe ini harus memiliki 2 (dua) unsur pokok, yaitu:18 (1) Perlindungan terhadap hak-hak asasi manusia; dan (2) Pemisahan kekuasaan dalam negara.

Namun dalam perkembangan tuntutan masyarakat tidak lagi menghendaki faham liberalisme ini dipertahankan, ${ }^{19}$ sehingga negara terpaksa turut campur tangan dalam urusan kepentingan rakyat, hanya saja masih dalam koridor saluran-saluran hukum yang telah ditentukan. Sejak itulah lahir negara hukum formil, ${ }^{20}$ yang dalam perspektif ini negara hanya dipandang sebagai instrument of power, akibatnya telah menimbulkan reaksi-reaksi dalam wujud pemikiran-pemikiran baru tentang suatu sistem yang baru, yaitu aliran-aliran yang tidak hanya memandang negara sebagai instrument of power saja, tetapi negara justeru dipandang sebagai agency of service. Maka timbullah konsep Welfare State (negara kesejahteraan/kemakmuran), ${ }^{21}$ yang terutama memandang

${ }^{18}$ Moh. Koesnardi dan Bintan R. Saragih, Op. Cit., hlm. 128.

${ }^{19}$ Faham liberalisme ini telah mengakibatkan negara hukum liberal itu hanya mementingkan individualisme, sedangkan kemampuan masing-masing individu tidaklah sama sehingga orang yang mempunyai kemampuan tinggi akan selalu menang dalam persaingan dengan orang yang tidak mampu yang dapat menimbulkan perbedaan yang sangat menonjol sehingga menimbulkan gejolak sosial (Lihat: Didi Nazmi Yunas, Konsepsi Negara Hukum, Cetakan ke-10, Angkasa Raya, Padang, 1992, hlm. 21 - 22).

${ }^{20}$ Pada negara hukum formil ini sebagaimana dikemukakan oleh F. J. Stahl unsurunsurnya bertambah menjadi 4 (empat) unsur dari yang semula hanya 2 (dua) unsur pada konsepsi negara hukum liberal yang telah dikemukakan oleh Immanuel Kant tersebut di atas. Keempat unsur negara hukum formil tersebut adalah: (1) Perlindungan terhadap Hak Asasi Manusia; (2) Pemisahan/pembagian kekuasaan; (3) Setiap tindakan pemerintah harus berdasarkan peraturan perundang-undangan yang telah ada; dan (4) Adanya Peradilan Administrasi yang berdiri sendiri (Lihat: Hasan Zaini, Pengantar Hukum Tata Negara Indonesia, Alumni Bandung, 1971, hlm. 154 - 155).

${ }^{21}$ Dalam literatur ilmu kenegaraan istilah lain untuk menyebut tipe negara ini lazim dikenal dengan istilah negara hukum materiil, yang sebenarnya merupakan perkembangan lebih lanjut dari konsepsi negara hukum formil. Dalam konsepsi negara hukum materiil ini tindakan dari penguasa dalam keadaan mendesak demi 
manusia tidak hanya sebagai individu, akan tetapi juga sebagai anggota atau warga dari suatu kolektivitas dan juga untuk tujuan diri sendiri. Dalam konsepsi negara kesejahteraan/kemakmuran ini, negara dituntut untuk memperluas tanggung jawabnya kepada masalah-masalah sosial ekonomi yang dihadapi oleh rakyat banyak, peran personal untuk menguasai hajat hidup rakyat banyak dihilangkan. Perkembangan inilah yang memberikan legislasi bagi negara intervensionis pada abad ke-20. Negara justeru perlu dan bahkan harus melakukan intervensi dalam berbagai masalah sosial dan ekonomi untuk menjamin terciptanya kesejahteraan bersama dalam masyarakat. ${ }^{22}$ Adapun yang menjadi ciriciri pokok dari suatu welfare state (negara kesejahteraan/kemakmuran) adalah sebagai berikut: ${ }^{23}$

1. Pemisahan kekuasaan berdasarkan trias politica dipandang tidak prinspiil lagi. Pertimbangan-pertimbangan efisiensi kerja lebih penting daripada pertimbangan-pertimbangan dari sudut politis, sehingga peranan dari organ-organ eksekutif lebih penting daripada organ legislatif;

2. Peranan negara tidak terbatas pada penjaga keamanan dan ketertiban saja, akan tetapi negara secara aktif berperanan dalam penyelenggaraan kepentingan rakyat di bidang-bidang sosial, ekonomi dan budaya, sehingga perencanaan (planning) merupakan alat yang penting dalam welfare state;

3. Welfare state merupakan negara hukum materiil yang mementingkan keadilan sosial dan bukan persamaan formil;

4. Hak milik tidak lagi dianggap sebagai hak yang mutlak, akan tetapi dipandang mempunyai fungsi sosial, yang berarti ada batas-batas dalam kebebasan penggunaannya; dan

5. Adanya kecenderungan bahwa peranan hukum publik semakin penting dan semakin mendesak peranan hukum perdata. Hal ini disebabkan karena semakin luasnya peranan negara dalam kehidupan sosial, ekonomi, dan budaya.

kepentingan warga negaranya dibenarkan bertindak menyimpang dari undangundang atau berlaku asas opportunitas. Sedangkan pada negara hukum formil, tindakan dari penguasa mutlak harus berdasarkan undang-undang atau berlaku asas legalitas. Tipe negara welfare state (negara hukum materiil) ini sering disebut sebagai negara hukum dalam arti yang luas atau juga disebut sebagai Negara Hukum Modern (Lihat: Abu Daud Busroh, Ilmu Negara, Cetakan ke-1, Bumi Aksara, Jakarta, 1990, hlm. 54. Sebagai pembanding, baca: Ni'matul Huda, Negara Hukum, Demokrasi dan Judicial Review, Cetakan ke-1, UII-Press, Yogyakarta, 2005, hlm. 7).

${ }^{22}$ Jimly Asshiddiqie, Gagasan Kedaulatan Rakyat dan Pelaksanaannya di Indonesia, Ichtiar Baru Van Hoeve, Jakarta, 1994, hlm. 222.

${ }^{23}$ Soerjono Soekanto, Beberapa Permasalahan Hukum dalam Kerangka Pembangunan di Indonesia, Yayasan Penerbit UI, Jakarta, 1975, hlm. 54 - 55. 
Welfare State (negara hukum materiil) telah menjadi trends negaranegara di dunia pada abad ke-20 (modern) ini. Akan tetapi, perlu disadari sebesar-besarnya bahwa dalam tipe negara hukum ini mudah sekali untuk timbulnya penyalahgunaan kekuasaan karena freis ermessen memegang peranan yang sangat banyak. Oleh karena itu, satu-satunya cara untuk menghindari penyalahgunaan ini, baik penyalahgunaan wewenang sendiri maupun penyalahgunaan wewenang yang bukan wewenangnya oleh alat perlengkapan negara lainnya, terutama sekali guna melindungi kepentingan rakyatnya, maka setiap alat perlengkapan negara harus berada di bawah suatu kontrol yang kuat serta sistematis melalui suatu sistem pertanggungjawaban tertentu. Apabila ternyata tidak dapat memberikan pertanggungjawaban yang telah ditentukan harus dikenakan sanksi-sanksi hukum sebagaimana mestinya. Untuk kepentingan ini adanya suatu peradilan administrasi menjadi urgen. ${ }^{24}$

\section{Negara Hukum Demokratis; Sintesisme Demokrasi dan Negara Hukum}

Sebagaimana telah dikatakan pada bagian pengantar dari tulisan ini bahwa demokrasi dan negara hukum adalah dua konsepsi yang saling berkaitan yang satu sama lainnya tidak dapat dipisahkan. Pada konsepsi demokrasi, di dalamnya terkandung prinsip-prinsip kedaulatan rakyat (democratie) sedangkan di dalam konsepsi negara hukum terkandung prinsip-prinsip negara hukum (nomocratie), yang masing-masing prinsip dari kedua konsepsi tersebut dijalankan secara beriringan sebagai dua sisi dari satu mata uang. Paham negara hukum yang demikian dikenal dengan sebutan "negara hukum yang demokratis" (democratische rechtsstaat) atau dalam bentuk konstitusional disebut constitutional democracy. ${ }^{25}$

Disebut sebagai "negara hukum yang demokratis", karena di dalamnya mengakomodasikan prinsip-prinsip negara hukum dan prinsipprinsip demokrasi, yaitu: ${ }^{26}$

${ }^{24}$ Joeniarto, Negara Hukum, Yayasan Badan Penerbit Gadjah Mada, Jogjakarta, 1960, hlm. 20.

${ }^{25}$ Jimly Asshiddiqie, Menuju Negara Hukum Yang Demokratis, Op. Cit., hlm. 690.

${ }^{26}$ J. B. J. M. Ten Berge, Besturen Door De Overheid, W. E. J. Tjeenk Willink, Deventer, 1996, hlm. 34 - 38 (Sebagai pembanding, baca: Ridwan HR., Hukum Administrasi Negara, UII-Press, Yogyakarta, 2002, hlm. 8 -10). 
I. Prinsip-prinsip Negara Hukum :

1) Asas legalitas, pembatasan kebebasan warga negara (oleh pemerintah) harus ditemukan dasarnya dalam undang-undang yang merupakan peraturan umum. Kemauan undang-undang itu harus memberikan jaminan (terhadap warga negara) dari tindakan (pemerintah) yang sewenang-wenang, kolusi, dan berbagai jenis tindakan yang tidak benar, pelaksanaan wewenang oleh organ pemerintah harus dikembalikan dasarnya pada undang-undang tertulis, yakni undang-undang formal;

2) Perlindungan hak-hak asasi manusia (HAM);

3) Keterikatan pemerintah pada hukum;

4) Monopoli paksaan pemerintah untuk menjamin penegakan hukum; dan

5) Pengawasan oleh hakim yang merdeka dalam hal organ-organ pemerintah melaksanakan dan menegakkan aturan-aturan hukum.

II. Prinsip-prinsip Demokrasi :

1) Perwakilan politik. Kekuasaan politik tertinggi dalam suatu Negara dan dalam masyarakat hokum yang lebih rendah diputuskan oleh badan perwakilan, yang diisi melalui pemilihan umum;

2) Pertanggungjawaban politik. Organ-organ pemerintahan dalam menjalankan fungsinya sedikit banyak tergantung secara politik yaitu kepada lembaga perwakilan;

3) Pemencaran kewenangan. Konsentrasi kekuasaan dalam masyarakat pada satu organ pemerintahan adalah kesewenang-wenangan. Oleh karena itu, kewenangan badan-badan publik itu harus dipencarkan pada organ-organ yang berbeda;

4) Pengawasan dan kontrol (penyelenggaraan) pemerintahan harus dapat dikontrol;

5) Kejujuran dan terbuka untuk umum; dan

6) Rakyat diberi kemungkinan untuk mengajukan keberatan.

Lebih lanjut Jimly Asshiddiqie, ${ }^{27}$ menegaskan bahwa negara hukum yang bertopang pada sistem demokrasi pada pokoknya mengidealkan suatu mekanisme bahwa negara hukum itu haruslah demokratis, dan negara demokrasi itu haruslah didasarkan atas hukum. Menurutnya, dalam perspektif yang bersifat horizontal gagasan demokrasi yang berdasarkan atas hukum (constitutional democracy) mengandung 4 (empat) prinsip pokok, yaitu:

1) Adanya jaminan persamaan dan kesetaraan dalam kehidupan bersama;

${ }^{27}$ Jimly Asshiddiqie, "Demokrasi dan Nomokrasi: Prasyarat Menuju Indonesia Baru", Kapita Selekta Teori Hukum (Kumpulan Tulisan Tersebar), FH-UI, Jakarta, 2000, hlm. 141 - 144). 
2) Pengakuan dan penghormatan terhadap perbedaan atau pluralitas;

3) Adanya aturan yang mengikat dan dijadikan sumber rujukan bersama; dan

4) Adanya mekanisme penyelesaian sengketa berdasarkan mekanisme aturan yang ditaati bersama dalam konteks kehidupan bernegara, di mana terkait pula dimensi-dimensi kekuasaan yang bersifat vertikal antar institusi negara dengan warga negara.

Dalam pandangannya, keempat prinsip-prinsip pokok dari demokrasi tersebut lazimnya dilembagakan dengan menambahkan prinsip-prinsip negara hukum (nomokrasi), yaitu:

1) Pengakuan dan penghormatan terhadap hak-hak asasi manusia;

2) Pembatasan kekuasaan melalui mekanisme kekuasaan dan pembagian kekuasaan disertai mekanisme penyelesaian sengketa ketatanegaraan antar lembaga negara, baik secara vertikal maupun horizontal;

3) Adanya peradilan yang bersifat independen dan tidak memihak (independent and impartial) dengan kewibawaan putusan yang tertinggi atas dasar keadilan dan kebenaran;

4) Dibentuknya lembaga peradilan yang khusus untuk menjamin keadilan warga negara yang dirugikan akibat putusan atau kebijakan pemerintahan (pejabat administrasi negara);

5) Adanya mekanisme judicial review oleh lembaga legislatif maupun lembaga eksekutif;

6) Dibuatnya konstitusi dan peraturan perundang-undangan yang mengatur jaminan-jaminan pelaksana prinsip-prinsip tersebut; dan

7) Pengakuan terhadap asas legalitas atau due process of law dalam keseluruhan sistem penyelenggaraan negara.

Oleh karena itu, negara hukum itu harus ditopang dengan sistem demokrasi karena terdapat korelasi yang jelas antara negara hukum yang bertumpu pada konstitusi, dengan kedaulatan rakyat yang dijalankan melalui sistem demokrasi. Dalam sistem demokrasi partisipasi rakyat merupakan esensi dari sistem ini. Akan tetapi, demokrasi tanpa pengaturan hukum akan kehilangan bentuk dan arah, sementara hukum tanpa demokrasi akan kehilangan makna. ${ }^{28}$ Menurut Frans Magnis Suseno, demokrasi yang bukan negara hukum bukan demokrasi dalam arti yang sesungguhnya. Demokrasi merupakan cara yang paling aman untuk mempertahankan kontrol atas negara hukum. ${ }^{29}$

\footnotetext{
${ }^{28}$ Ridwan HR., Op. Cit., hlm. 7.

${ }^{29}$ Frans Magnis Suseno, Mencari Sosok Demokrasi; Sebuah Telaah Filosofis, Gramedia, Jakarta, 1997, hlm. 58.
} 
Dengan demikian dalam negara hukum yang demokratis, hukum dibangun dan ditegakkan menurut prinsip-prinsip demokrasi. Hukum tidak boleh dibuat, ditetapkan, ditafsirkan, dan ditegakkan dengan "tangan besi" berdasarkan kekuasaan semata (machtsstaat). Sebaliknya, demokrasi haruslah diatur berdasar atas hukum (rechtsstaat) karena perwujudan gagasan demokrasi memerlukan instrumen hukum untuk mencegah munculnya mobokrasi, ${ }^{30}$ yang mengancam pelaksanaan demokrasi itu sendiri. ${ }^{31}$

\section{Negara Hukum "Indonesia" Yang Demokratis}

Indonesia, sebagai negara yang terlahir pada abad modern melalui Proklamasi 17 Agustus 1945 juga "mengklaim" dirinya sebagai negara hukum. Hal ini terindikasikan dari adanya suatu ciri negara hukum yang prinsip-prinsipnya dapat dilihat pada Konstitusi Negara R. I. (sebelum dilakukan perubahan), yaitu dalam Pembukaan UUD 1945, Batang Tubuh (non Pasal-pasal tentang HAM), dan Penjelasan UUD 1945 dengan rincian sebagai berikut: ${ }^{32}$

1. Pembukaan UUD 1945, memuat dalam alinea pertama kata "perikeadilan", dalam alinea kedua "adil", serta dalam alinea keempat terdapat perkataan "keadilan sosial", dan "kemanusiaan yang adil". Semua istilah itu berindikasi kepada pengertian negara hukum, karena bukankah suatu tujuan hukum itu untuk mencapai negara keadilan. Kemudian dalam Pembukaan UUD 1945 pada alinea keempat juga ditegaskan "maka disusunlah kemerdekaan kebangsaan Indonesia itu dalam suatu Undang-undang Dasar Negara Indonesia".

2. Batang Tubuh UUD 1945, menyatakan bahwa "Presiden Republik Indonesia memegang kekuasaan pemerintahan menurut Undangundang Dasar (Pasal 14). Ketentuan ini menunjukkan bahwa presiden dalam menjalankan tugasnya harus mengikuti ketentuan-ketentuan yang sudah ditetapkan dalam Undang-undang Dasar. Pasal 9 mengenai sumpah Presiden dan Wakil Presiden "memegang teguh Undang-Undang Dasar dan menjalankan segala undang-undang dan peraturannya selurus-lurusnya". Melarang Presiden dan Wakil Presiden menyimpang dari peraturan perundang-undangan yang

${ }^{30}$ Mobokrasi adalah terminologi yang diperkenalkan oleh Aristoteles untuk menyebut bentuk pemerosotan dari demokrasi.

${ }^{31}$ Jimly Asshiddiqie, Menuju Negara Hukum Yang Demokratis, Loc. Cit.

${ }^{32}$ Dahlan Thaib, Kedaulatan Rakyat, Negara Hukum, dan Konstitusi, Cetakan ke-2, Liberty, Yogyakarta, 2000, hlm. 25 - 26. 
berlaku dalam menjalankan tugasnya suatu sumpah yang harus dihormati oleh Presiden dan Wakil Presiden dalam mempertahankan asas negara hukum. Ketentuan ini dipertegas lagi oleh Pasal 27 UUD 1945 yang menetapkan bahwa "segala warga negara bersamaan kedudukannya dalam hukum dan pemerintahan itu dengan tidak ada kecualinya". Pasal ini selain menjamin prinsip equality before the law, suatu hak demokrasi yang fundamental, juga menegaskan kewajiban warga negara untuk menjunjung tinggi hukum suatu prasyarat langgengnya negara hukum; dan

3. Penjelasan UUD 1945, merupakan penjelasan autentik dan menurut Hukum Tata Negara Indonesia, Penjelasan UUD 1945 itu mempunyai nilai yuridis, dengan huruf besar menyatakan: "Negara Indonesia berdasarkan atas hukum (rechtsstaat) tidak berdasarkan atas kekuasaan belaka (machtsstaat)". Ketentuan yang terakhir ini menjelaskan apa yang tersirat dan tersurat telah dinyatakan dalam Batang Tubuh UUD 1945.

Dari ketiga ketentuan di atas, penegasan secara eksplisit Indonesia sebagai negara hukum dapat dijumpai dalam Penjelasan UUD 1945. Lain halnya dengan dua konstitusi (Konstitusi RIS dan UUDS 1950) yang pernah berlaku di Indonesia, terdapat penegasan secara eksplisit rumusan Indonesia sebagai negara hukum. Dalam Mukaddimah Konstitusi RIS misalnya disebutkan pada alinea ke-4; "untuk mewujudkan kebahagiaan, kesejahteraan, perdamaian, dan kemerdekaan dalam masyarakat dan negara hukum Indonesia Merdeka yang berdaulat sempurna". Kemudian di dalam Pasal 1 ayat (1) Konstitusi RIS juga disebutkan; "Republik Indonesia Serikat yang merdeka dan berdaulat ialah suatu Negara hukum yang demokrasi dan berbentuk federasi".

Demikian pula halnya, di dalam Mukaddimah UUDS 1950 pada alinea keempat menyebutkan:

Maka demi ini kami menyusun kemerdekaan kami itu dalam suatu Piagam Negara yang berbentuk Republik Kesatuan, berdasar pengakuan Ketuhanan Yang Maha Esa, Perikemanusiaan, Kebangsaan, Kerakyatan dan Keadilan Sosial untuk mewujudkan kebahagiaan, kesejahteraan, perdamaian, dan kemerdekaan dalam masyarakat dan negara hukum Indonesia Merdeka yang berdaulat sempurna.

Kemudian di dalam Pasal 1 ayat (1) UUDS 1950 disebutkan; Republik Indonesia yang merdeka dan berdaulat ialah negara hukum yang demokratis dan berbentuk kesatuan.

Setelah UUD 1945 dilakukan perubahan, rumusan negara hukum Indonesia yang semula hanya dimuat secara implisit baik di dalam 
Pembukaan maupun Batang Tubuh UUD 1945 dan secara eksplisit dimuat di dalam Penjelasan UUD 1945, penempatan rumusan negara hukum Indonesia telah bergeser kedalam Batang Tubuh UUD 1945 yang secara tegas dinyatakan di dalam Pasal 1 ayat (3) UUD 1945 yang berbunyi: Negara Indonesia adalah Negara Hukum. Jika dikaitkan dengan unsur-unsur negara hukum sebagaimana uraian pada pembahasan di atas, maka dapat ditemukan pengaturan unsur-unsur negara hukum dalam Batang Tubuh UUD 1945 sebagai berikut:

1. Perlindungan terhadap hak-hak asasi manusia (HAM);3

2. Pemisahan / pembagian kekuasaan; ${ }^{34}$

3. Pemerintahan berdasarkan undang-undang; ${ }^{35}$ dan

4. Peradilan administrasi yang berdiri sendiri. ${ }^{36}$

${ }^{33}$ Perlindungan terhadap HAM di dalam UUD 1945 (sebelum perubahan) selain telah dijamin pengaturannya pada Pembukaan UUD 1945, juga telah diatur dalam Batang Tubuh UUD 1945 yaitu dalam Pasal-pasal 27, 28, 29, 30, 31, dan Pasal 34. Kemudian setelah UUD 1945 dilakukan perubahan, perlindungan terhadap HAM telah dijamin pengaturannya lebih komprehensif lagi jika dibandingkan dengan UUD 1945 sebelum perubahan yang dituangkan dalam pasal-pasal HAM pada bab tersendiri yaitu Bab X A dengan judul "Hak Asasi Manusia", dan di dalamnya terdapat 10 pasal tentang HAM ditambah 1 pasal (pasal 28) dari bab sebelumnya (Bab X) tentang "Warga Negara dan Penduduk", sehingga ada 11 pasal tentang HAM mulai dari Pasal 28, 28 A sampai dengan Pasal $28 \mathrm{~J}$.

${ }^{34}$ UUD 1945 sebelum perubahan menganut paham pembagian kekuasaan secara vertikal, bukan pemisahan kekuasaan yang bersifat horizontal. Dalam hal ini kedaulatan rakyat dianggap terwujud penuh dalam wadah MPR yang dapat ditafsirkan sebagai lembaga tertinggi ataupun sebagai forum tertinggi. Dari sini, fungsi-fungsi tertentu dibagikan sebagai tugas dan kewenangan lembaga-lembaga tinggi negara yang ada di bawahnya, yaitu Presiden, DPR, MA, dan seterusnya. Akan tetapi, dalam Perubahan Pertama dan Kedua UUD 1945, prinsip pemisahan kekuasaan secara horizontal jelas mulai dianut oleh para perumus Perubahan UUD 1945 seperti tercermin dalam Perubahan Pasal 5 ayat (1) dan Pasal 20 ayat (1) sampai ayat (5).

${ }^{35}$ Sebagai suatu negara hukum berdasarkan UUD 1945, Presiden RI memegang kekuasaan pemerintahan menurut UUD, Presiden berhak mengajukan RUU kepada DPR. Presiden menetapkan PP untuk menjalankan UU sebagaimana mestinya. Semua ketentuan UUD 1945 itu merupakan hukum positif yang menjadi dasar konstitusional (Constitutionale atau Grondwettelyke Grondslag) dari adanya sifat wetmatigheid van het bestuur, seperti yang telah termuat di dalam Pasal 4 ayat (1) dan Pasal 5 ayat (1) dan (2) UUD 1945.

${ }^{36}$ Meskipun keberadaan peradilan administrasi (administrative court) merupakan ciri khas negara hukum liberal yang lebih mengutamakan perlindungan terhadap hak asasi individu, namun dalam negara hukum Indonesia yang berdasarkan cita Negara Pancasila peradilan administrasi negara bukanlah unsur utama, melainkan unsur turunannya yang diturunkan dari unsur utama karena dalam cita Negara 
Dengan demikian, dalam sistem konstitusi Negara Indonesia cita negara hukum itu menjadi bagian yang tak terpisahkan dari perkembangan gagasan kenegaraan Indonesia sejak kemerdekaan. Meskipun dalam pasal-pasal UUD 1945 sebelum perubahan, ide negara hukum itu tidak dirumuskan secara eksplisit, tetapi dalam penjelasannya ditegaskan bahwa Indonesia menganut ide 'rechtsstaat', bukan 'machtsstaat'. Sementara dalam Konstitusi RIS Tahun 1949, ide negara hukum itu bahkan tegas dicantumkan, demikian pula dalam UUDS 1950, kembali rumusan bahwa Indonesia adalah negara hukum dicantumkan dengan tegas. Bahkan dalam Perubahan Ketiga pada tahun 2001 terhadap UUD Negara RI Tahun 1945, ketentuan mengenai negara hukum ini kembali dicantumkan secara tegas dalam Pasal 1 ayat (3) yang berbunyi: "Negara Indonesia adalah Negara Hukum". Oleh karena itu, secara teoritis gagasan kenegaraan Indonesia telah memenuhi persyaratan sebagai negara hukum modern, yaitu negara hukum yang demokratis dan bahkan menganut pula paham negara kesejahteraan (welfare-state).

\section{Penutup}

Negara hukum itu harus ditopang dengan sistem demokrasi karena terdapat korelasi yang jelas antara negara hukum yang bertumpu pada konstitusi, dengan kedaulatan rakyat yang dijalankan melalui sistem demokrasi. Dalam sistem demokrasi partisipasi rakyat merupakan esensi dari sistem ini. Akan tetapi, demokrasi tanpa pengaturan hukum akan kehilangan bentuk dan arah, sementara hukum tanpa demokrasi akan kehilangan makna. Negara hukum yang demokratis, hukum dibangun dan ditegakkan menurut prinsip-prinsip demokrasi. Hukum tidak boleh dibuat, ditetapkan, ditafsirkan, dan ditegakkan dengan "tangan besi"

Pancasila lebih mengutamakan masyarakat daripada individu, tetapi tidak berarti bahwa individu tidak mendapatkan tempat sama sekali melainkan harkat dan martabat manusia tetap diperhatikan. Dengan demikian, keberadaan peradilan administrasi negara di Indonesia merupakan salah satu sarana untuk memberikan perlindungan terhadap hak asasi manusia (HAM) dengan cara melakukan pengawasan atau kontrol judicial terhadap pemerintahan sebagai wujud pengakuan dan perlindungan terhadap hak-hak warga negara. Maka, kepada rakyat harus diberi kesempatan untuk menggugat pegawai atau instansi pemerintahan yang melakukan kesalahan dan yang menurut mereka dianggap merugikan hak-hak mereka, sehingga adanya peradilan administrasi diharapkan dapat memberikan jaminan tegaknya keadilan bagi tiap-tiap warga negara. 
berdasarkan kekuasaan semata (machtsstaat). Sebaliknya, demokrasi haruslah diatur berdasar atas hukum (rechtsstaat) karena perwujudan gagasan demokrasi memerlukan instrumen hukum untuk mencegah munculnya mobokrasi, yang mengancam pelaksanaan demokrasi itu sendiri.

\section{Daftar Pustaka}

Abu Daud Busroh, Ilmu Negara, Cetakan ke-1, Bumi Aksara, Jakarta, 1990.

Afan Gaffar, Politik Indonesia: Transisi Menuju Demokrasi, Pustaka Pelajar, Yogyakarta, 2005.

Dahlan Thaib, Kedaulatan Rakyat, Negara Hukum, dan Konstitusi, Cetakan ke-2, Liberty, Yogyakarta, 2000.

Deliar Noer, Pengantar Ke Pemikiran Politik, CV. Rajawali, Jakarta, 1983.

Didi Nazmi Yunas, Konsepsi Negara Hukum, Cetakan ke-10, Angkasa Raya, Padang, 1992.

Frans Magnis Suseno, Mencari Sosok Demokrasi: Sebuah Telaah Filosofis, Gramedia, Jakarta, 1997.

, Etika Politik: Prinsip-prinsip Moral Dasar Kenegaraan Modern, PT. Gramedia Pustaka Utama, Jakarta, 1999.

Hasan Zaini, Pengantar Hukum Tata Negara Indonesia, Alumni, Bandung, 1971.

Jimly Asshiddiqie, Gagasan Kedaulatan Rakyat dan Pelaksanaannya di Indonesia, Ichtiar Baru Van Hoove, Jakarta, 1994. , Kapita Selekta Teori Hukum (kumpulan Tulisan Tersebar), FH-UI, Jakarta, 2000.

, Konstitusi dan Konstitusionalisme Indonesia, Edisi Revisi, Konstitusi Press, Jakarta, 2005.

, Menuju Negara Hukum Yang Demokratis, Sekretariat Jenderal dan Kepaniteraan Mahkamah Konstitusi, Jakarta, 2008.

Joeniarto, Negara Hukum, Yayasan Penerbit Gadjah Mada, Jogjakarta, 1960. Miriam Budiardjo, Masalah Kenegaraan, Gramedia, Jakarta, 1982. Dasar-dasar Ilmu Politik, Cetakan ke-7, Gramedia, Jakarta, 1996.

Moh. Koesnardi dan Bintan R. Saragih, Ilmu Negara, Cetakan ke-2, Gaya Media Pratama, Jakarta, 1988. dan Harmaily Ibrahim, Pengantar Hukum Tata Negara, Cetakan ke7, Pusat Studi HTN FH-UI, Jakarta, 1988.

Nakamura dan Samallowood, The Polities of Policy Implementation, st. Martin's Press, New York, 1980. 
Ni'matul Huda, Negara Hukum, Demokrasi dan Judicial Review, Cetakan ke-1, UII-Press, Yogyakarta, 2005.

Padmo Wahjono, Membudayakan UUD 1945, IND HILL-Co, Jakarta, 1991. Ridwan HR., Hukum Admnistrasi Negara, UII-Press, Yogyakarta, 2002.

Robert A. Dahl, Dilema Demokrasi Pluralis: Antara otonomi dan Kontrol, terjemahan Sahat Simamora, Rajawali Press, Jakarta, 1985.

Soerjono Soekanto, Beberapa Permasalahan Hukum dalam Kerangka Pembangunan di Indonesia, Yayasan Penerbit UI, Jakarta, 1975. 